\title{
Tick-borne spotted fever in the northeast of Brazil: the series of cases a new endemic area
}

\section{Febre maculosa transmitida por carrapatos no nordeste do Brasil: a série de casos de uma nova área endêmica}

\author{
Stefan Vilges de Oliveira ${ }^{1}$. \\ 1 Health Surveillance Secretariat of the Ministry of Health, Brasília, Distrito Federal, Brazil, National Reference Laboratory for \\ Rickettsial disease Vectors of the Oswaldo Cruz Foundation, Rio de Janeiro, Rio de Janeiro, Brazil, Graduate Program in Tropical \\ Medicine at the University of Brasília, Brasília, Distrito Federal, Brazil.
}

\section{Dear Editor,}

The Brazilian states of the northeastern region are considered silent areas for the occurrence of cases of spotted fever (SF), either by the low frequency of suspicion or the confirmation on cases of the disease. ${ }^{1}$

In 2010 it was notified to the Ministry of Health (MH) of Brazil the first case of SF in the State of Ceará. ${ }^{2}$ The case has been identified in the city of Aratuba, which is located in the Maciço region of Baturité. This region is at an average altitude of nine hundred meters above sea level, has hot humid tropical climate and the Atlantic rainforest it's the predominant vegetation, surrounded by areas of open shrubby caatinga and thorny deciduous forest. ${ }^{3}$

Analyzing the records of the Notifiable Diseases Information System of MH, it was found that the following years were reported 74 suspected cases of SF, which were laboratory confirmed 14 cases that met the definition of SF case proposed by $\mathrm{MH}$ (serological evidence of the fourfold change in immunoglobulin $\mathrm{G}$ ( $\mathrm{IgG})$ - specific antibody titers reactive to Rickettsia spotted fever group antigens by indirect immunofluorescence assay between paired serum samples (one taken in the first week of illness and the second 2-4 weeks later)). ${ }^{4}$ The cities that occurred infections were Aratuba, Baturité, Guaramiranga and Pacoti, all located in the same geomorphological region of Ceará.

Analyzing the epidemiological characteristics on this series of cases it is observed that the SF affects men and women, aged 50-64 years, primarily brown individuals. The largest number of infections record was observed in the countryside and the affected individuals reported exposure to ticks (13/14), dogs and cats (4/14) and horses (2/14). Most cases began to show symptoms of the disease between the months of April to November. Just one case needed to be hospitalized and none of the cases caused death. The most frequent symptoms were fever $(100 \%$; 14/14), headache $(78.5 \%$; 11/14), myalgias $(78.5 \% ; 11 / 14)$, rash $(50 \%, 7 / 14)$, and lymphadenopathy $(42.8,6 / 14)$. Other less common symptoms were conjunctival hyperemia, respiratory distress, prostration, diarrhea, nausea,

vomiting, abdominal pain and necrosis. In epidemiological research it was also possible to identify the scar of inoculation eschar in a patient of Aratuba city (lesion at the site where the tick was joined) (Figure 1).

Figure 1. Scar of inoculation eschar (lesion at the site where the tick was stuck) in confirmed case of spotted fever in the city of Aratuba-Ceará.

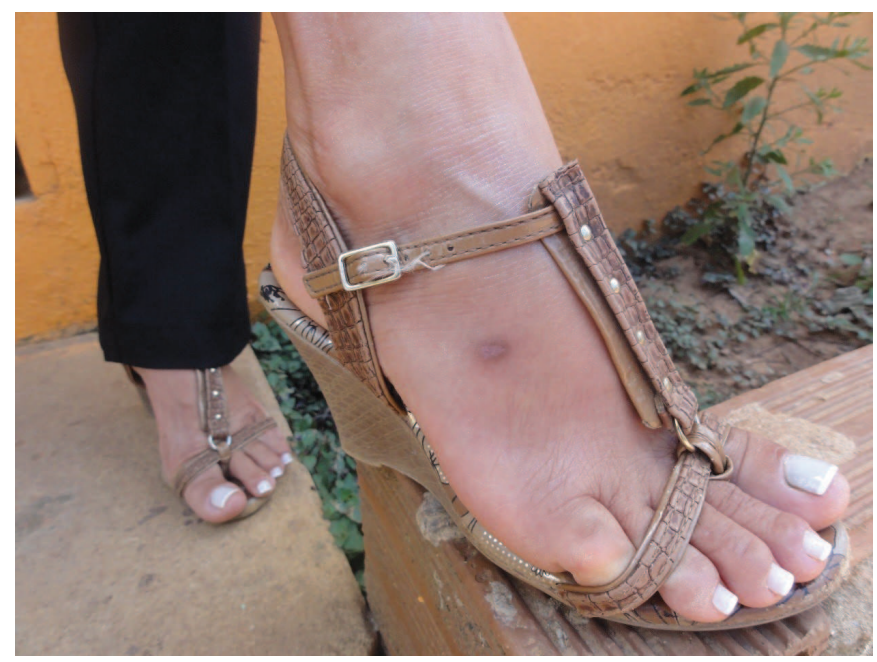

Source: prepared by the authors.

These data corroborate with the findings of Spolidorio et al., 5 Silva et al., ${ }^{6}$ and Krawczak et al., ${ }^{7}$ that described cases of SF in the states of São Paulo, Bahia and Santa Catarina, caused by Rickettsia sp. strain Atlantic rainforest and has clinical features as the presence of lifadenopatia and eschar inoculation. These studies were characterized through the molecular biology of rickettsia strain by lesion biopsy and inoculation eschar, which is therefore the necessary laboratory method to determine the species that causes SF on Ceará.

Moerbeck et al., ${ }^{8}$ conducted a research to vectors of fauna and species of Rickettsia in these areas and the data found makes us suggest that Rickettsia sp. strain Atlantic rainforest 
is the specie responsible for infections in the Maciço region of Baturite and the vector is the tick Amblyomma ovale.

The evidences we have so far point to a transmission scenario in Ceará involving the domestic dog as an amplifier of the distribution area of ticks $A$. ovale. The transmitter sites of the Rickettsia sp. strain Atlantic rainforest shows as common characteristics the presence of forest environments in the proximity of homes and occurring infections when the dog does translocation of ticks for the domicile and/or around the

\section{REFERENCES}

1. Oliveira SV, Pereira SV, Pinna FV, Fonseca LX, Serra-Freire NM, Cardoso KM, et al. Vigilância de ambientes da febre maculosa: explorando as áreas silenciosas do Brasil. Rev Pan-Amaz Saúde. 2016;7(3):65-72.

2. Oliveira SV, Guimarães JN, Reckziegel GC, Neves BM, AraújoVilges KM, Fonseca LX, et al. An update on the epidemiological situation of spotted fever in Brazil. J Venom Anim Toxins incl Trop Dis. 2016;22;(1):22.

3. Superintendência Estadual do Meio Ambiente do Ceará [Internet]. Área de proteção ambiental da Serra de Baturité. Fortaleza: Semace; [date unknown] [cited 2016 Aug 29]. Available from: http://www. semace.ce.gov.br/2010/12/apa-da-serra-de-baturite/

4. Brasil. Ministério da Saúde. Secretaria de Vigilância em Saúde. Guia de vigilância em saúde. Febre maculosa brasileira e outras riquetsioses. Brasília: Ministério da saúde; 2016 [cited 2016 Aug 29]. Available from: http://portalsaude.saude.gov.br/images/pdf/2016/ agosto/25/GVS-online.pdf

5. Spolidorio MG, Labruna MB, Mantovani E, Brandão $P E$, Richtzenhain LJ, Yoshinari NH. Novel spotted fever group rickettsiosis, Brazil. Emerg Infect Dis. 2010;16(3):521-3.

6. Silva N, Eremeeva ME, Rozental T, Ribeiro GS, Paddock CD, Ramos EA, et al. Eschar-associated spotted fever rickettsiosis, Bahia, Brazil. Emerg Infect Dis. 2011;17(2):275-8.

7. Krawczak FS, Munoz-Leal S, Guztazaky AC, Oliveira SV, Santos domicile, or when individuals go into these forest fragments, coming to be parasitized for this specie of tick. ${ }^{9-12}$

Faced with the limitations about the knowledge of the clinic evolution of these cases of infections caused by Rickettsia sp. strain Atlantic rainforest the epidemiological conducts of surveillance and medical assistence should be followed according to the guidelines that the Ministry of Health recommends. ${ }^{4}$

FC, Angerami RN, et al. Rickettsia sp. strain Atlantic rainforest infection in a patient from a spotted fever-endemic area in southern Brazil. Am J Trop Med Hyg. 2016;95(3):551-3.

8. Moerbeck L, Vizzoni VF, Machado-Ferreira E, Cavalcante RC, Oliveira SV, Soares CA, Amorim M, Gazeta GS. Rickettsia (Rickettsiales: Rickettsiaceae) vector biodiversity in high altitude atlantic forest fragments within a semiarid climate: a new endemic area of spotted-fever in Brazil. J Med Entomol [Internet]. 2016 [cited 2016 Aug 29]. Available from: http://jme.oxfordjournals.org/content/ early/2016/07/31/jme.tjw121

9. Szabó MP, Pinter A, Labruna MB. Ecology, biology and distribution of spotted-fever tick vectors in Brazil. Front Cell Infect Microbiol. 2013;3(27):1-9.

10. Barbieri AR, Jonas Filho M, Nieri-Bastos FA, Souza JC, Szabó MP, Labruna MB. Epidemiology of Rickettsia sp. strain atlantic rainforest in a spotted fever-endemic area of southern Brazil. Ticks Tick Borne Dis. 2014;5(6):848-53.

11. Vizzoni VF, Silva AB, Cardoso KM, Santos FB, Stenzel B, Amorim M, et al. Genetic identification of Rickettsia sp. strain atlantic rainforest in an endemic area of a mild spotted fever in Rio Grande do Sul state, Southern Brazil. Acta Trop. 2016;162:142-5.

12. Krawczak FS, Binder LC, Oliveira CS, Costa FB, Moraes-Filho J, Martins TF, et al. Ecology of a tick-borne spotted fever in southern Brazil. Exp Appl Acarol. 2016;70(2):219-29.

Corresponding Author: Stefan Vilges de Oliveira, Health Surveillance Secretariat of the Ministry of Health, Setor Comercial Sul, quadra 04, bloco A, edifício Principal, 30 andar, Brasília, Distrito Federal, Brazil. CEP: 70304-904.Telefone: +55 61 3213-8232/98105-3118. E-mail: stefanbio@yahoo.com.br Conflict of interests: The authors have no conflicts of interest to declare.

Received: 06 Sep 2016; Revised: 10 Oct 2016; Accepted: 10 Oct 2016.

Como citar:

Oliveira SV. Tick-borne spotted fever in the northeast of Brazil: the series of cases a new endemic area. Rev Med UFC. 2016 jul-dez;56(2):8-9. 